\title{
State of charge and state of health determination model for a lead-acid battery to be implemented in a management system
}

\author{
J. Hernández, A. F. Campos \& R. Gómez \\ Research Laboratory of Alternative Energy Sources, \\ Distrital University Francisco José de Caldas, Colombia
}

\begin{abstract}
Battery Energy Storage Systems (BESS) are essential for performing a suitable energy management from renewable sources. They are therefore a necessary element of the new trends of smart grids and micro-grids. This paper proposes a storage system through independent battery strings to increment cycles of use during their lifespan and take advantage of the maximum extracted energy, which has a direct impact on reducing investment and operating costs. Hence, Battery Management Systems (BMS) are indispensable to improve the BESS's performance since they allow working with independent battery strings to connect and disconnect independently, depending on the load requirements. This paper seeks to validate a lead-acid battery model from measurements in terms of State of Charge (SOC), State of Health (SOH) and terminal voltage. Therefore, it is important to check different models that match with these applications' requirements. Since the final selection of the model depends on the parameters that shape it, it is necessary to study different methods for determination of SOC and $\mathrm{SOH}$ of the batteries to classify them according to their complexity and uncertainty for the set up advantages and disadvantages of each one. A MATLABSimulink ${ }^{\circledR}$ simulation of a model is made as an example, where the measurement matches the model's elements, allowing us to obtain basic values such as SOC, $\mathrm{SOH}$, depth of discharge (DOD) and terminal voltage simulated under a previously established uncertainty value. This paper leaves a path opened to allow for a future study about the implementation of a BMS to control properly each one of the battery strings that compose a BESS.

Keywords: battery energy storage system, lead-acid battery, state of charge, state of health, depth of discharge, battery model, battery management system.
\end{abstract}




\section{Introduction}

BESS have limitations regarding optimal cycling operation and maximum parallel strings (Standard IEEE 1491 of 2012 [1]). Further, it recommends using the same number of parallel and series strings (Standard IEEE 485 of 2010 [2]). However, manufacturer recommendations limit the parallel strings to four, as you see in figure 1(a), due the possibility of a voltage imbalance between them and the cell with lower voltage predominates.

BESS in independent configuration use control devices to connect and disconnect strings depending of load conditions and cell states (Rahimi-Eichi et al. [3]). In figure 1(b) this configuration is shown; so there are no limits in parallel strings comparing with conventional configuration. Thus, the total cycles with independent strings will be the sum of available cycles of each string, unlike conventional configuration where total cycles are the available cycles of one string because the BESS is under the same charge and discharge rate. Therefore, our raised configuration brings advantages in terms of maximum useful energy, backup, redundancy and maintenance (Standard IEEE 1187 of 2002 [4]).

To validate those advantages of independent configuration, measurements of electric features on a 2.3 Ah lead-acid battery were carried out in terms of SOC and $\mathrm{SOH}$. Those measurements were applied in a MATLAB-SIMULINK ${ }^{\circledR}$ to determinate the remaining cycles and useful life. This papers is organized as follows: Section 2, Review of battery models; Section 3, SOC and SOH estimation methods; Section 4, Chosen model and estimation methods; Section 5, Battery modelling; Section 6, Results; Section 7, Conclusions.

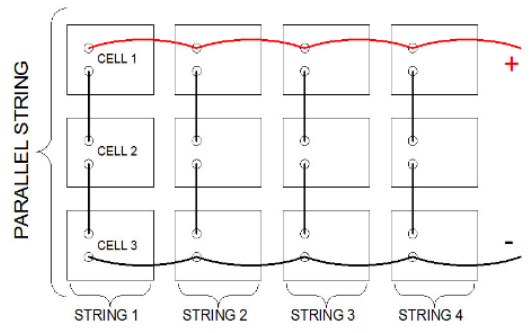

(a)

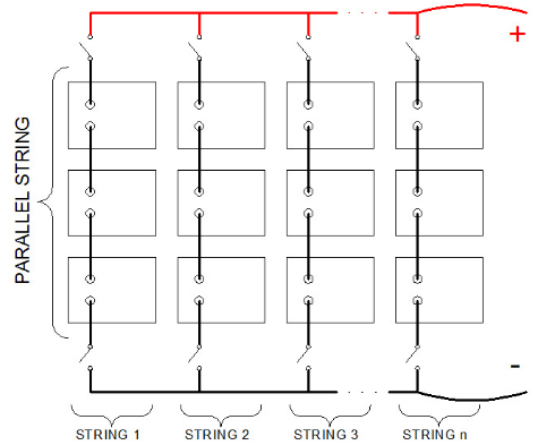

(b)

Figure 1: BESS on (a) conventional configuration and (b) independent configuration.

\section{Battery models}

There are a lot of battery models developed by researchers with different complexities in order to meet battery behavior in specific purposes, for example battery design, performance estimation and circuit simulation (Chen and Rincon- 
Mora [5]). Among battery models (Kai and Qifang [6]), three main groups stand out (as shown in figure 2): Electrochemical, Mathematical and Electric models.

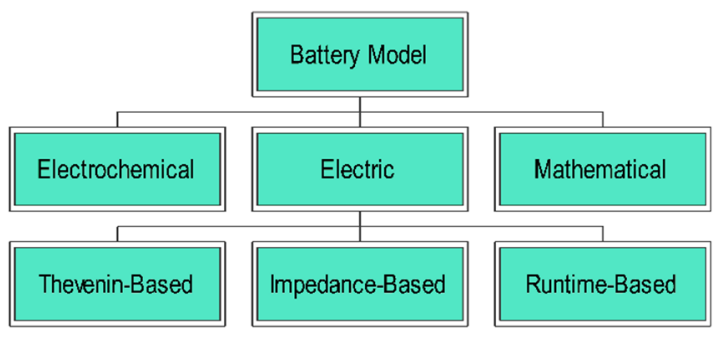

Figure 2: $\quad$ Main groups of battery models.

Dees et al. [7] used electrochemical models with design purposes to fit these parameters with information a macroscopic and microscopic level, but they suffer from long simulation time due to complex algorithms and parameters difficult to obtain according to Santhanagopalan et al. [8] and Rao et al. [9]. Mathematical models use empirical equations or mathematical methods such as stochastic approaches to predict parameters like efficiency and capacity (Salameh et al. [10] and Gomadam et al. [11]). However, they work only in specific applications and Rong and Pedram [12] showed an error percentage between 5 and 20\%. Finally, electrical models are the most accurate models because they have an error between 1 and 5\%, also they work in co-simulation with other models since they use an equivalent electrical circuit thought resistors, capacitors and voltage sources (Rao et al. [9]); therefore they are very useful in different applications. According to Chen and Rincon-Mora [5], it is possible to group electrical models in three groups (as seen in figure 3), Thevenin-based, impedance-based and runtime-based.

-Thevenin-based: It uses series resistors with a RC parallel network that predicts transient response in a particular SOC. Consequently, it is not possible to determinate voltage variations in steady state because the parameters are assumed constant (Durr et al. [13]).

-Impedance-based: It uses the spectroscopy impedance to obtain an equivalent AC impedance model on frequency domain (modeling electrochemical behavior). Also uses a complex equivalent network to adjust impedance spectrum, so it works for a particular SOC and temperature.

-Runtime-based: It uses a complex circuit to simulate battery operation and obtain the DC voltage response for a constant current, but it is not accurate with variable charges. It is able to model transients, self-discharge resistance and voltage drops due internal losses.

However, within these three battery models there are a lot of models developed for specific applications. Durr et al. [13] showed the simplest model. It represents an ideal battery with an electric source $E_{0}$ and constant internal resistor ESR (battery fully charge) as shown in figure 4, being useful only in applications where the SOC is not an important parameter. Similarly, Chan and Sutanto [14] showed a modification of that model assuming a variable internal resistor according to SOC behavior, eqn. (1), where $R_{0}$ is the resistance when the battery is fully 


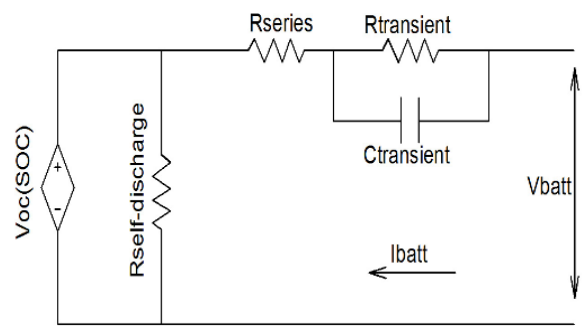

(a)

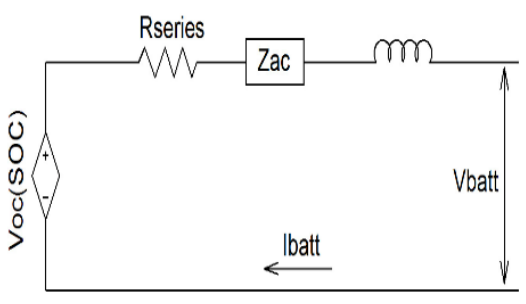

(b)

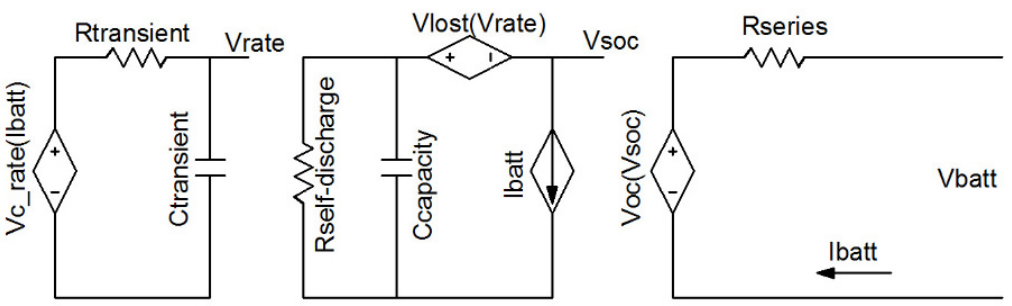

(c)

Figure 3: Battery models based on (a) Thevenin, (b) Impedance and (c) Runtime [6].

charged, $S$ is the SOC that changes between 0 (fully discharged) and 1 (fully charged), and $\mathrm{K}$ is a coefficient in function of rate of discharge determined by manufacturer data (Peukert function). $S$ is defined in eqn. (2), where $C_{10}$ is the capacity (Ah) in a 10 hour discharge rate (Cun et al. [15]).

$$
\begin{gathered}
E S R=\frac{R o}{S^{k}} \\
S=1-\frac{A h}{C_{10}}
\end{gathered}
$$

Improvements in some models are focused in the representation of the battery dynamic behavior (Chan et al. [14]), takes into account the nonlinearity of the open circuit voltage (Voc) and the internal resistance, also showed a overcurrent model that requires a lot of parameters to meet a good representation of voltage variations due SOC. Kai and Qifang [6] showed a fourth-order dynamic model; this one is accurate because it represents electrolyte behavior, ohmic effect and the battery age. Even so, it suffers from two drawbacks, a long time simulation and need empiric information due to its fourth grade. Chen and Rincon-Mora [5] developed a model that combines features of the three main groups, it is able to predict runtime operation, steady state and transient response. Durr et al. [13] implemented a nonlinear dynamic model as a variation of Thevenin based where, 
separating the charge and discharge process, it estimated the relationship between Voc and SOC.

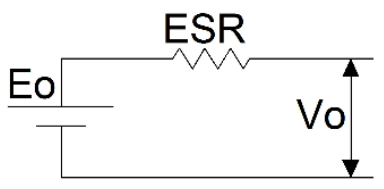

Figure 4: The simplest battery model [15].

\section{SOC and SOH estimation methods}

Rahimi-Eichi and Chow [16] described the SOC as the percentage that defines the remaining capacity of the battery, that is to say, the relationship between rated capacity and the net amount of charge of a discharged battery. Mathematically, Codecà et al. [17] defines it as:

$$
\operatorname{SOC}(t)=\frac{A h_{\text {nom }}-\int_{0}^{t} I(t) d t}{A h_{\text {nom }}}
$$

where $I(t)$ is the extracted current from the battery (positive in discharge) and $A h_{\text {nom }}$ is the rated capacity.

While SOC is a well-known parameter of the remaining capacity, $\mathrm{SOH}$ that is supposed as state indicator, it has not been defined yet, Rahimi-Eichi et al. [3]. Some authors (Kim [18]), define it like the ability to store charge, supply high currents and maintain charge for long periods; another authors have said that $\mathrm{SOH}$ is an indicator of lifespan and a measure of relative condition compared with a new battery (Xiong et al. [19]). However, many of them agree with the following equation to define this parameter $[3,20]$ :

$$
\operatorname{SOH}(\%)=\frac{Q_{A C T}}{Q_{R}} * 100
$$

where $Q_{R}$ is the rated capacity and $Q_{A C T}$ is the current battery capacity that is degraded by several macroscopic and microscopic phenomena present during cycling.

Currently, many methods to estimate the SOC and $\mathrm{SOH}$ have been presented: Codeca et al. [21] showed Ah counting, discharge test used by Coleman et al. [22], Roscher and Sauer [23] used the Voc-SOC relationship, impedance spectroscopy is explained by Lindahl et al. [24], a review of DC internal resistance is done by Huet [25], Xiong et al. [19] developed a kalman filter, Singh et al. [26] used a fuzzy logic, among others (Piller et al. [27]). Each of them has advantages and disadvantages on its implementation. Table 1 shows a brief summary of estimation methods commonly used. 
Table 1: Advantages and disadvantages of estimation methods.

\begin{tabular}{|c|c|c|c|c|}
\hline METHOD & $\begin{array}{c}\text { FIELD OF } \\
\text { APPLICATION }\end{array}$ & $\begin{array}{c}\text { SUITABLE } \\
\text { BATTERY } \\
\text { MODEL } \\
\end{array}$ & ADVANTAGES & DISADVANTAGES \\
\hline Ah Counting & $\begin{array}{l}\text { All battery } \\
\text { systems, most } \\
\text { applications }\end{array}$ & $\begin{array}{l}\text { Thevenin } \\
\text { Model }\end{array}$ & $\begin{array}{l}\text { Online, accurate if } \\
\text { recalibration of } \\
\text { measurement } \\
\text { equipment is } \\
\text { available } \\
\end{array}$ & $\begin{array}{l}\text { Initial value of SOC, } \\
\text { model for the losses, } \\
\text { intensive cost in } \\
\text { calibration, sensitive } \\
\text { to parasite reactions }\end{array}$ \\
\hline $\begin{array}{l}\text { Discharge } \\
\text { Test }\end{array}$ & $\begin{array}{l}\text { All battery } \\
\text { systems, most } \\
\text { applications }\end{array}$ & $\begin{array}{l}\text { Impedance } \\
\text { Model }\end{array}$ & $\begin{array}{l}\text { Easy, accurate, } \\
\text { strong SOH } \\
\text { indicator }\end{array}$ & $\begin{array}{c}\text { Offline, time } \\
\text { intensive, loss of } \\
\text { energy and lifespan } \\
\text { due frequent deep } \\
\text { discharges }\end{array}$ \\
\hline $\begin{array}{l}\text { OCV-SOC } \\
\text { Relationship }\end{array}$ & $\begin{array}{l}\text { Lead, Lithium, } \\
\text { Zn/Br, } \\
\text { VA group }\end{array}$ & $\begin{array}{c}\text { Thevenin } \\
\text { Model }\end{array}$ & $\begin{array}{l}\text { Online, cheap, } \\
\text { SOH estimation } \\
\text { trough Q-VOC } \\
\text { curve }\end{array}$ & $\begin{array}{l}\text { Problems with acid } \\
\text { stratification, needs } \\
\text { long rest time, } \\
\text { sensitive to parasite } \\
\text { reactions, low } \\
\text { dynamic }\end{array}$ \\
\hline $\begin{array}{l}\text { Physical } \\
\text { Properties of } \\
\text { Electrolyte }\end{array}$ & $\begin{array}{l}\text { Only liquid } \\
\text { electrolyte } \\
\text { batteries }\end{array}$ & $\begin{array}{l}\text { Electro- } \\
\text { chemical } \\
\text { Model }\end{array}$ & $\begin{array}{l}\text { Online, } \mathrm{SOH} \\
\text { indicator }\end{array}$ & $\begin{array}{l}\text { Problems with acid } \\
\text { stratification, low } \\
\text { dynamic, sensitive to } \\
\text { temperature and } \\
\text { impurities }\end{array}$ \\
\hline $\begin{array}{l}\text { Impedance } \\
\text { Spectroscopy }\end{array}$ & $\begin{array}{l}\text { All battery } \\
\text { systems }\end{array}$ & $\begin{array}{l}\text { Impedance } \\
\text { Model }\end{array}$ & $\begin{array}{c}\text { Online, } \mathrm{SOH} \\
\text { indicator and } \\
\text { battery lifespan }\end{array}$ & $\begin{array}{l}\text { Intensive cost and } \\
\text { time, specific } \\
\text { equipment, sensitive } \\
\text { to temperature }\end{array}$ \\
\hline $\begin{array}{l}\text { D. C. Internal } \\
\text { Resistance }\end{array}$ & $\begin{array}{l}\text { Lead, Ni-Cd, } \\
\text { Lithium, Ni-Mh }\end{array}$ & $\begin{array}{l}\text { Runtime } \\
\text { Model }\end{array}$ & $\begin{array}{l}\text { SOH estimation, } \\
\text { cheap, easy, online }\end{array}$ & $\begin{array}{l}\text { Good accuracy in } \\
\text { short time intervals, } \\
\text { sensitive to } \\
\text { temperature }\end{array}$ \\
\hline $\begin{array}{l}\text { Neural } \\
\text { Networks }\end{array}$ & $\begin{array}{l}\text { All battery } \\
\text { systems, most } \\
\text { applications }\end{array}$ & $\begin{array}{l}\text { Runtime } \\
\text { Model }\end{array}$ & Online, accurate & $\begin{array}{l}\text { Needs training data, } \\
\text { limitation on inputs } \\
\text { variables, intensive } \\
\text { cost }\end{array}$ \\
\hline Kalman Filters & $\begin{array}{l}\text { All battery } \\
\text { systems, most } \\
\text { applications }\end{array}$ & $\begin{array}{c}\text { Thevenin } \\
\text { Model }\end{array}$ & $\begin{array}{l}\text { Online, dynamic, } \\
\text { accurate, } \mathrm{SOH} \\
\text { estimation }\end{array}$ & $\begin{array}{c}\text { Need large } \\
\text { computing capacity } \\
\text { and suitable battery } \\
\text { model, difficult to } \\
\text { implement }\end{array}$ \\
\hline $\begin{array}{c}\text { Heuristic } \\
\text { Interpretation }\end{array}$ & $\begin{array}{c}\text { Applications } \\
\text { with frequently } \\
\text { fully charge, few } \\
\text { changes in SOC } \\
\text { and low currents } \\
\end{array}$ & $\begin{array}{l}\text { Impedance } \\
\text { Model }\end{array}$ & $\begin{array}{l}\text { Online, cheap, } \\
\text { easy }\end{array}$ & $\begin{array}{l}\text { Needs reference data } \\
\text { for fitting } \\
\text { parameters }\end{array}$ \\
\hline Fuzzy Logic & $\begin{array}{l}\text { All battery } \\
\text { systems }\end{array}$ & $\begin{array}{l}\text { Impedance } \\
\text { Model }\end{array}$ & $\begin{array}{c}\text { Online, doesn't } \\
\text { need mathematical } \\
\text { models and } \\
\text { preliminary } \\
\text { history, robust }\end{array}$ & $\begin{array}{l}\text { Large amount of } \\
\text { memory and need } \\
\text { large computing } \\
\text { capacity }\end{array}$ \\
\hline
\end{tabular}




\section{Chosen model and estimation methods}

Based on Section 2, we chose a modification of the battery model presented in figure 4, taking into account that: our model needs the steady state response, model parameters are easier to obtain with estimation methods related in section 3 , it requires a low computing power due its low complexity by having a dependent source and a variable resistor that represent the dynamic behavior as consequence of SOC and SOH respectively.

Consistent with the chosen model, it is used Ah counting method to estimate the SOC. The SOH is estimate with the DC internal resistance method. Those methods are the most common methods, cheap and easy to implement, also they require a low computing power and meet the expected uncertainty. Another important factor is that there is no suitable equipment in our laboratory to implement methods with lower uncertainty (i.e. spectroscope).

\section{Battery modelling}

\subsection{Measurements}

To ensure that temperature was constant, all the tests were carried out at $25^{\circ} \mathrm{C}$ in a temperature controlled chamber, measuring the current and voltage of Mtek $12 \mathrm{~V}$ 2.3Ah VRLA Lead-Acid Battery (MT1223) through a current sensor ACS714ELC-20A and operational amplifiers to measure voltage like signal conditioning. Those signals were taken by the data acquisition system performed in LABVIEW $^{\circledR}$ to store and calculate significant parameters (SOC, DOD, Voc, internal resistance, total cycles and operating time) during the discharge and charge process.

The battery's initial internal resistance at $25^{\circ} \mathrm{C}$ with the battery fully charged was 0.060 ohms. That was the starting point that allowed the analysis of battery state during the cycles. Table 2 gives a summary of charge and discharge rates used during the test. You can notice that are three rates of discharge, recommended by the manufacturer.

Table 2: Discharge and charge rate information.

\begin{tabular}{|c|c|c|c|c|c|}
\hline \multicolumn{4}{|c|}{ Discharge } & \multicolumn{2}{c|}{ Charge } \\
\hline $\begin{array}{c}\text { Discharge } \\
\text { Mode }\end{array}$ & \multicolumn{3}{|c|}{ Constant Load } & $\begin{array}{c}\text { Maximum } \\
\text { Charge } \\
\text { Current (A) }\end{array}$ & 0.69 \\
\hline DOD & $1 \mathrm{C}$ & $0.5 \mathrm{C}$ & $0.1 \mathrm{C}$ & $\begin{array}{c}\text { Float } \\
\text { Voltage (V) }\end{array}$ & 13.6 to 13.8 \\
\hline Rate & 24 & 48 & 240 & $\begin{array}{c}\text { Cycling } \\
\text { Voltage (V) }\end{array}$ & 14.5 to 14.9 \\
\hline Time (min) & & \multicolumn{3}{|c|}{$40 \%$} & \\
\hline
\end{tabular}




\subsection{Modeling}

In MATLAB-Simulink ${ }^{\circledR}$ Sim Power System library there is a battery model with a dependent voltage source (in function of SOC) and a series resistance. This model simulates Lithium-Ion, Nickel-Cadmium, Nickel-Metal and Lead-Acid batteries through terminal voltage variations by having hysteresis effect between charge and discharge voltage. However, this model has a constant internal resistance unchanged regarding to age and discharge current. Also, temperature does not affect the battery behavior, and there is not memory effect and selfdischarge [28].

Based on this model, this paper proposes a variable internal resistor that represents SOC and $\mathrm{SOH}$ behavior unlike constant resistor and its limitations. This variable resistor is modelled through a dependent voltage source simulating the voltage drop in this resistor and thus obtain more real terminal voltages in function of time and rate of discharge. This variable resistor is modelled in function of Voc limited by manufacturer values, where the minimum resistor value is when the battery is fully charged and the maximum value is when the SOC is 0 . The results of this model will be analyzed in the next section.

\section{Results}

Figure 5 shows the behavior of internal resistance at a $0.5 \mathrm{C}$ rate compared with its simulation. This resistance measured is affected by measure devices resolution. Durr et al. [13] took an internal resistance measurement and this one remains constant almost all rates of discharge and it grows in an exponential way at the end of the cycle. The behavior of the internal resistor at $1 \mathrm{C}, 0.5 \mathrm{C}$ and $0.1 \mathrm{C}$ are shown in figure 6 , where the internal resistor grows proportionally to the rate, which means, $\mathrm{SOH}$ is inversely proportional to the internal resistance function.

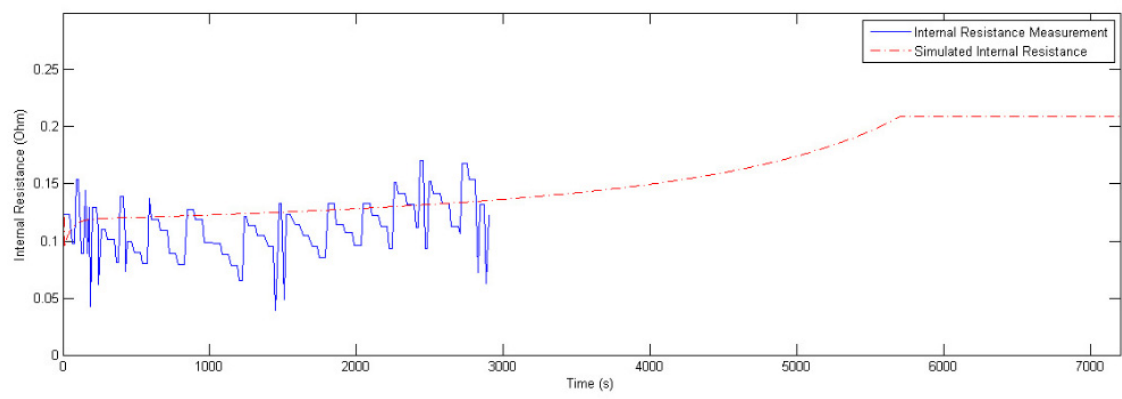

Figure 5: Internal resistance measured and simulated.

In figure 7 the terminal voltage on a $0.5 \mathrm{C}$ rate is observed, where the value measured is similar to the value simulated until $40 \%$ DOD. As in the previous measurements, the maximum error is $2 \%$ near to exponential zone of the voltage signal. Figure 8 summarizes the terminal voltage signals of the three rates, where 


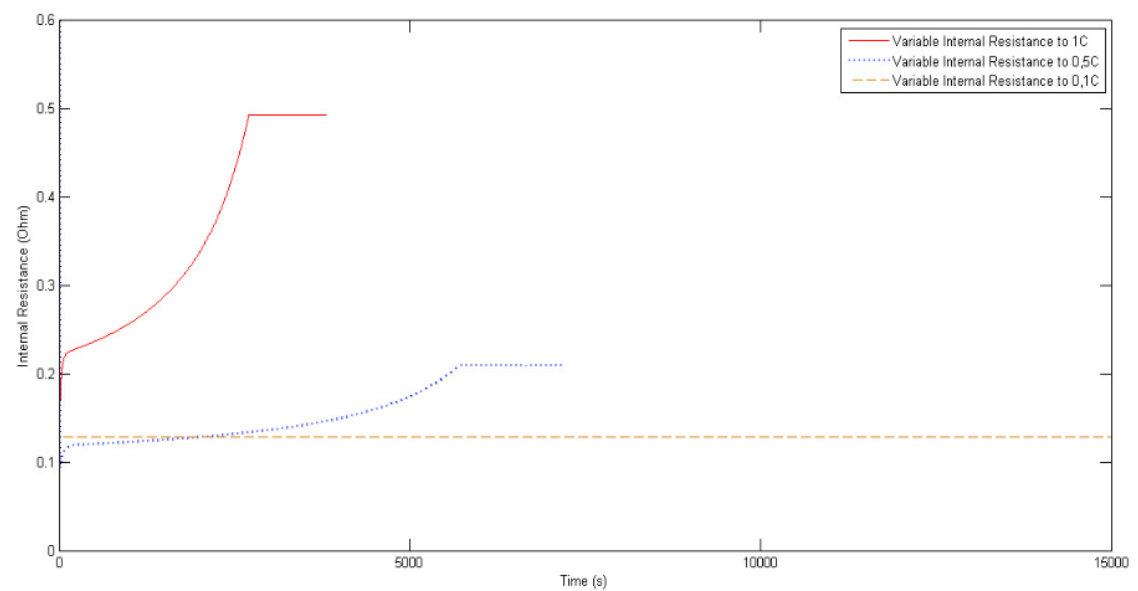

Figure 6: Comparison of internal resistance among differing rates of discharge.

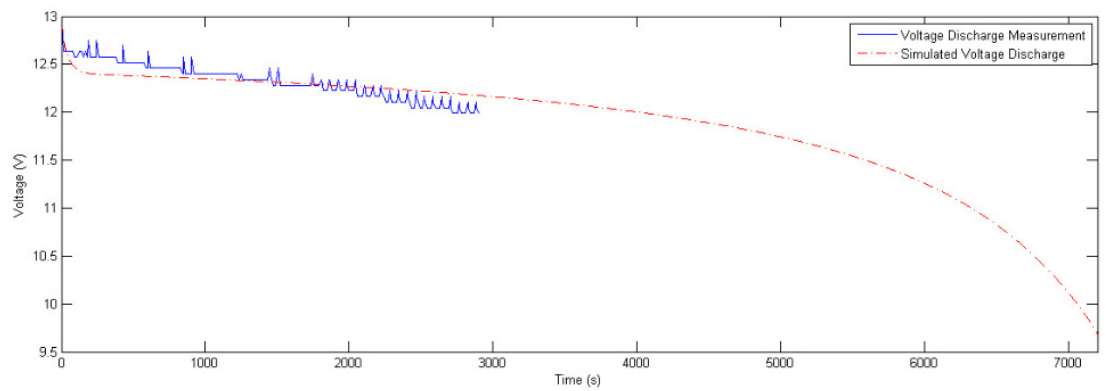

Figure 7: Discharge voltage measured and simulated.

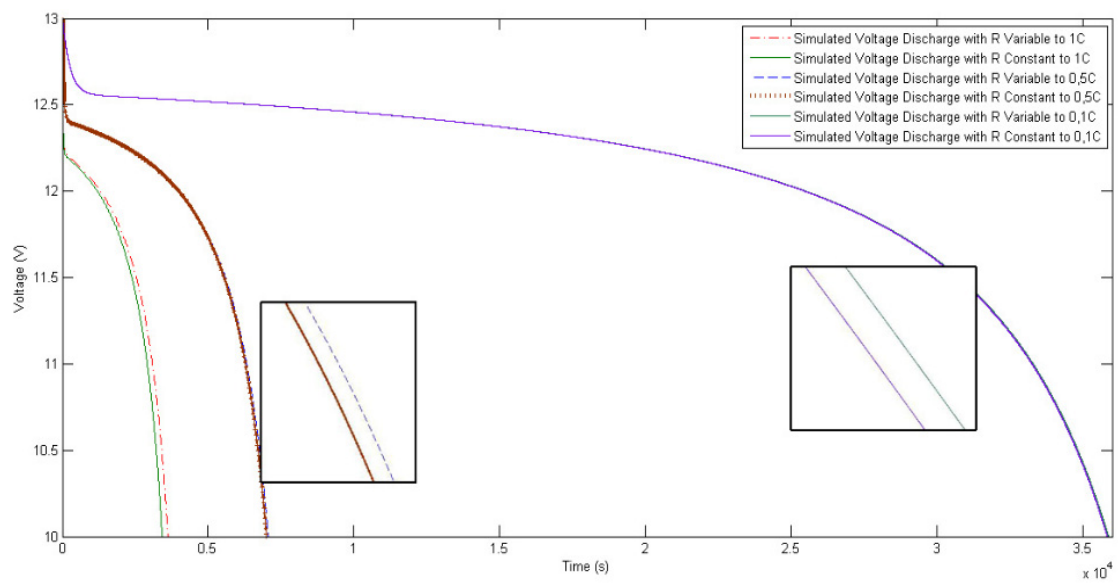

Figure 8: Simulated discharge voltage discharge among differing rates of discharge. 
each of them are compared with a constant and variable resistor model, evidencing that a variable resistor model does not change the discharge voltage behaviour, simulating the voltage response in a more real way as Tremblay and Dessaint [28] showed.

Relating to SOC, figure 9 compares the measured and simulated results on a $0.5 \mathrm{C}$ rate where the behavior is more accurate, since it depends largely on the discharge current (this parameter is measured with an appropriate device with high precision). Similarly, the behavior between constant and variable resistor model are similar so the error tends to 0 .

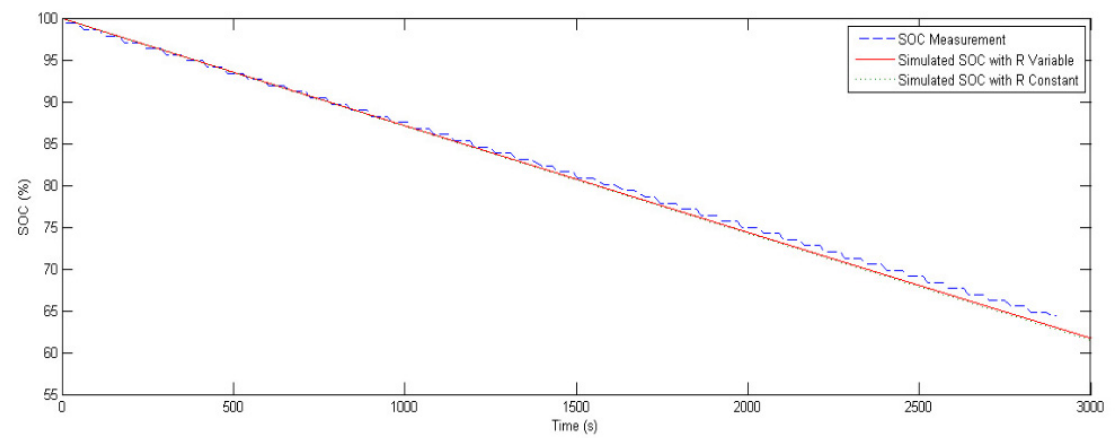

Figure 9: $\quad$ SOC measured and simulated.

\section{Conclusion}

A change at the MATLAB-Simulink ${ }^{\circledR}$ model was done in the SimPowerSystems library, where it introduces a variable behavior of the internal resistance taking into account SOC and $\mathrm{SOH}$, reflecting measured parameters without change the model behavior from a $12 \mathrm{~V} 2.3 \mathrm{Ah}$ lead-acid battery with $40 \% \mathrm{DOD}$. Ah counting method was suitable to estimating SOC, whereas internal resistance measurement to estimating $\mathrm{SOH}$ presented the worst error among all measurements, so this method is still difficult to obtain. Therefore, the uncertainty degree depends on largely of the measurement devices, since to obtain results more accurate is need using devices with a better resolution and exactness, to make a reliable measurement.

A review of the battery models and estimation methods of SOC and $\mathrm{SOH}$ was done and it is presented a table related with these parameters according to their advantages and disadvantages, so each estimation method matches with a model where it could be implemented.

\section{References}

[1] International Standard Association, IEEE Std 1491 - Guide for Selection and Use of Battery Monitoring Equipment in Stationary Applications, New York, 2012. 
[2] International Standard Association, IEEE Std 485 - Recommended Practice for Sizing Lead-Acid Batteries for Stationary Applications, New York, 2010.

[3] Rahimi-Eichi, H., Ojha, U., Baonti, F. \& Chow, M.Y., Battery Management System: An Overview of Its Application in the Smart Grid and Electric Vehicles. IEEE Industrial Electronics Magazine, 7(2), pp. 4-16, 2013.

[4] International Standard Association, IEEE Std 1187 - Recommended Practice for Installation Design and Installation of Valve-Regulated LeadAcid Storage Batteries for Stationary Applications, New York, 2002.

[5] Chen, M., \& Rincon-Mora, G., Accurate Electrical Battery Model Capable of Predicting Runtime and I-V Performance. IEEE Transactions On Energy Conversion, 21(2), pp. 504-511, 2006.

[6] Kai, S., \& Qifang, S., Overview of the Types of Battery Models. Proceedings of the 30th Chinese Control Conference, Yantai, China, 2011.

[7] Dees, D.W., Battaglia, V.S., \& Bélanger, A., Electrochemical modeling of lithium polymer batteries. Journal of Power Source, 110(2), pp. 310-320, 2002.

[8] Santhanagopalan, S., Guo, Q., \& Ramadass, P., Review of models for predicting the cycling performance of lithium ion batteries. Journal of Power Sources, 156(2), pp. 620-628, 2006.

[9] Rao, R., Vrudhula, S., \& Rakhmatov, D.N., Battery modeling for energyaware system design, IEEE Computer, 36(12), pp. 77-87, 2003.

[10] Salameh, Z., Casacca, M. \& Lynch, W. A., A mathematical model for leadacid batteries. IEEE Transactions on Energy Conversion, 7(1), pp. 93-98, 1992.

[11] Gomadam, P. M., Weidner, J. M., Dougal, R.A., \& White, R.E., Mathematical modeling of lithium-ion and nickel battery systems. Journal of Power Source, 110(2), pp. 267-284, 2002.

[12] Rong, P., \& Pedram, M., An analytical model for predicting the remaining battery capacity of lithium-ion batteries. IEEE Transactions on Very Large Scale Integration (VLSI) Systems, 14(5), pp. 441-451, 2006.

[13] Durr, M., Cruden, A., Gair, S., \& McDonald, J., Dynamic Model of a LeadAcid Battery for Use in a Domestic Fuel Cell System. Journal of Power Source, 161(2), pp. 1400-1411, 2006.

[14] Chan, H., \& Sutanto, D., A New Battery Model for use with battery energy storage systems and electric vehicles Power system. IEEE Power Engineering Society Winter Meeting, 1, pp. 470-475, 2000.

[15] Cun, J.P., Fiorina, J.N., Fraisse, M. \& Mabboux, H., The experience of a UPS company in advanced battery monitoring. 18th International IEEE Telecommunications Energy Conference, Boston, MA, 1996.

[16] Rahimi-Eichi, H., \& Chow, M.Y., Modeling and Analysis of Battery Hysteresis Effects. IEEE Energy Conversion Congress and Exposition (ECCE), Raleigh, NC, 2012.

[17] Codecà, F., Savaresi, S.M., \& Manzoni, V., The Mix Estimation algorithm for battery State-of-Charge Estimator - Analysis of the Sensitivity to 
Measurement Errors. Proceedings of the 48th IEEE Conference on Decision and Control, Shanghai, China, 2009.

[18] Kim, I.-S., A Technique for Estimating the State of Health of Lithium Batteries Through a Dual-Sliding-Mode Observer. IEEE Transactions on Power Electronics, 25(4), pp. 1013-1022, 2010.

[19] Xiong, R., Sun, F., Chen, Z. \& He, H., A Data-Driven Multi-Scale Extended Kalman Filtering Based Parameter and State Estimation Approach of Lithium-Ion Polymer Battery in Electric Vehicles. Elsevier: Applied Energy, 113, pp. 463-476, 2014.

[20] Ng, K.S., Moo, C.S., Chen, Y.P., \& Hsieh, Y.C., Enhanced Coulomb Counting Method for Estimating State-of-Charge and State-of-Health of Lithium-Ion Batteries. Journal of Applied Energy, 86(9), pp. 1506-1511, 2009.

[21] Codecà, F., Savaresi, S.M., \& Rizzoni, G., On battery State of Charge Estimation: A New Mixed Algorithm. IEEE International Conference on Control Applications, San Antonio, TX, pp. 102-107, 2008.

[22] Coleman, M., Lee, C.K., Zhu, C., \& Hurley, W.G., State-of-Charge Determination From EMF Voltage Estimation: Using Impedance, Terminal Voltage, and Current for Lead-Acid and Lithium-Ion Batteries. IEEE Transactions on Industrial Electronics, 54(5), pp. 2550-2557, 2007.

[23] Roscher, M. A., \& Sauer, D.U., Dynamic Electric Behavior and OpenCircuit-Voltage Modeling of LiFePO4-based Lithium Ion Secondary Batteries. Journal of Power Sources, 196(1), pp. 331-336, 2011.

[24] Lindahl, P.A., Cornachione, M.A., \& Shaw, S.R., A Time-Domain Least Squares Approach to Electrochemical Impedance Spectroscopy. IEEE Transactions on Instrumentation and Measurement, 61(12), pp. 3303-3311, 2012.

[25] Huet, F., A Review of Impedance Measurements for Determination of the State-of-Charge or State-of-Health of Secondary Batteries. Journal of Power Sources, 70(1), pp. 59-69, 1998.

[26] Singh, P., Fennie Jr., C., \& Reisner, D., Fuzzy Logic Modelling of State-ofCharge and Available Capacity of Nickel/Metal Hydride Batteries. Journal of Power Sources, 136(2), pp. 322-333, 2004.

[27] Piller, S., Perrin, M., \& Jossen, A., Methods of State of Charge Determination and their Applications. Journal of Power Sources, 96(1), pp. 113-120, 2001.

[28] Tremblay, O., \& Dessaint, L.A., Experimental Validation of a Battery Dynamic Model for EV Applications. World Electric Vehicle Journal, 3, 2009. 